\title{
Improving the Economic and Mathematical Methods for Analyzing and Reducing Current State of Debt Among the Entities
}

\author{
Ruzimuradov Shuhrat Husanovich \\ Central Bank of the Republic Uzbekistan, Head of Division, Uzbekistan \\ Self-Researcher of Chair of Econometrics, Department of Cash and Monetary Circulation Tashkent State Economy University, \\ Uzbekistan
}

https://doi.org/10.47814/ijssrr.v4i1.58

\begin{abstract}
The collection of information on non-payments in the banking sector and their compact presentation in the matrix form in accordance with the required rules, the creation of various economic models (equities) of non-payments, elimination of different non-payment consequences and analysis are the intermediate scientific research goal of the article.
\end{abstract}

Keyword: Non-Payments; Non-Payment Reasons; Econometric Models of Non-Payments; Non-Payment Vector; Non-Payment Dynamics; Economic Mechanisms of Eliminating Non-Payments

\section{Introduction}

Today the whole world community as well as Uzbekistan have not found yetan acceptable way and method to solve the problem of liquidation receivable and payable balances. We can see that the problem of debts is really one of the most important issues of macroeconomics which should be considered in the following opinions:

As it was given in the report "Debts and financial crisis" prepared by Wee Chian Koh, M. Ayhan Kose, Peter S. Nagle, Franziska L. Ohnsorge and Naotaka Suguwara, the specialists of the World Bank: "Since the global financial crisis, global debt has reached an all-time high of roughly 230 percent of GDP in $2018 \ldots$ Rising or elevated debt increases a country's vulnerability to economic and financial shocks including increases in the cost of refinanciang which can culminate in financial crises, with large and lasting adverse effects on economic activity." (1).

During the enlarged session of the Cabinet of Ministers devoted to basic results of the socialeconomic development in Uzbekistan in 2016 and to primary course of the economic program targeted on 2017 the president of Uzbekistan Shavkat Mirziyev not without purpose reviewed such issues as "Why is the backlog of payment discipline observed? During the last 3 years, the accounts receivable in sum of 12 billion sum or $60 \%$ from 18 billion sum in total has being postponed. Why does the Minister of Finance being at the head of the appropriate committee or the Chairman of the Central Bank concern with it?" (2). 
It is well known that in spite of the level of the development of any country the share of receivables and payables among the entities is very high in the framework of the problems of debts in economy. Here it is significant to note that the lack of working capital or its backlog to the debt within the entities because it was not repaid in time curbs the effective activity of the entities. Untimely payment for the delivered goods, rendered services, performed work, and loans received for temporally use as well as accrued interest on them brings to flow the progressive chain of non-payments among the entities related by economic relationship. And this in turn requires to work out perfect theoretic base appropriate to market tendency as well as accelerator mechanism applied for introducing in practice to solve the problem of debts among the entities. Therefore, the issue of finding an acceptable way on problem of debts among entities by economicmathematical method was chosen as the subject of our research work.

Thus improving economic-mathematical methods that would prevent the occurrence of "chain of nonpayment" among entities and provide constant supply of assets circulating in economy by means of necessary facilities for their activity are the main and actual subjects facing the economic scientists today. Despite of scientific works aimed at solving that problem conducted by such scientific researches as S.G. Cecchetti,F.Zampolli,M.R.Moghadam,M.Tomaselli,A.A.Smolenski,A.P.Mihaylov,M.G.Delyagin,V.N.Mi heev,A.N.Katulev,G.V.Kolesnik,D.O.Chuhlantsev,N.N.Kalitkin,P.Galanzi,B.Gromanova,O.V.Amurjuev, A.E.Dorogavtsev and a number of other economic scientists their proposed methods, theoretical ideas and views as the result of their research have not being introduced into practice yet in any country today because there is no theoretic base which would be worked out perfectly and mechanism appropriate to market tendency to solve the problem of debts by economic-mathematical methods. As regards it, some foreign scientists and specialists said the following:

Italian economic scientist Matteo Tomaselli in his research work "Economic growth and public debt: beyond debt-thresholds" (2017-2018) wrote: "The large fiscal imbalances created worldwide by the Great Recession of 2008 revived general interest in the issue and focused the attention on the developed countries. One main problem is that a consistent theoretical framework for the debtgrow research is still missing”. (3)

As Russian scientist Michail Delyaginn pointed: “.....only because of inadequate macroeconomic measures ....it is difficult to understand the problem of nonpayment to solve it in its level of today because its combined pattern. The main reason of the growth of nonpayment is not only because of low of financial discipline and strict financial policy but because of inadequate financial infrastructure to solve closed flow of progressive nonpayment automatically" (4. p. 235)

Referred to above we see that the problem of debts among the entities is one of the most actual issues which should be solved today in many countries. It should be noted that naturally the state structure is the main responsible for solving and finding an acceptable solution for the problem of debts among the entities. Since many years of experience and development of countries with different management system shows that different disproportions arise because market mechanism cannot provide full and constant stability of the economy.

Economic scientist N.Kobrinskyi said about it the following: "During a long time the theory of English economist J.M.Keynes was the general but not only base applied to different model to regulate macroeconomics. The main idea of this theory is that the government should interfere in the management of any branch of the economy" (5; p.320). 
The first President of Uzbekistan I.A.Karimov, paying special attention at regulation of the economy by the government, said the following:

"We put at us the task to realize a longtime and continuing national interest by the received reforms and models of modernization resides in Uzbekistan. And first of all we recede from very easy and deceptive idea that market economy is regulated by itself as well as method of "shock therapy" proposed by foreign countries to introduce it." (6; p.5)

From that it follows that macroeconomic issues including the problem of debts among the entities arising from the lack of market power, cannot be solved only by economic instruments but without intervention of the government in necessary framework too. Because today government comes to nothing more than to analyze macroeconomic indicators and apply mechanism and instruments of monetary and fiscal policy in order to solve the problem of debts among the entities and that is not enough to solve this problem.

It should be noted that government should interfere in problem of debts on the base of definite theoretical knowledge and indicators of current position and facilities using the modern accelerator mechanisms. If the government gets an acceptable solution without analyzing appropriate important and actual issues duly or interferes in economy by not following market trends and without reason (taking into account different political views, interests of any definite group or any other goals) then such government intervene would not give a good result.

There it is naturally emerged the question: in what branch of economy, when, and by what entity or economic instruments and mechanism and to what extent it is necessary to exert government interfere? Today despite strong development of economic theory, there is no definite and valid answer to those questions.

Abovementioned opinions show the necessity that it should be conducted widespread fundamental investigation on the question: when, by what economic instruments and mechanism, and to what extent should the government interfere in order to solve the problem of debts.

Therefore, in this research work we put forward the question of analysis of the current position in the problem of debts among the entities and finding out acceptable solution in order to solve it only by economic instruments and in time - that is the government should interfere in "definite branch" of economy by market mechanism, in necessary framework and validly in order to solve the problem of debts.

For that purpose, our object is to improve theoretical and methodological base of acceptable solution on the problem of debts conducting fundamental investigation on reducing the problem of debts among the entities by the economic-mathematical methods suitable for a market economy.

Thus to analyze the current position of the problem of debts among the entities and improve theoretical and methodological base of the economic-mathematical methods which would allow to find out acceptable solution taking into account market tendency is the main task of our scientific research work. the entities.

The subject of the scientific research is the problem of receivables and payables balances among 
The subject matter of our research is:

- information of current position of debts among entities in electron file;

- flow of current position of debts among entities;

- economic-mathematical models of current position of debts among entities;

- economic-mathematical methods on analyzing and reducing;

- existent theoretical proposals to find out acceptable solution, proposed economic-mathematical methods to solve that problem, the results of research work of scientists on that issue.

Carrying out the scientific research in studying and analyzing the problem of debts among the entities and finding out acceptable solution on it by economic-mathematical methods there will be used dialectics, analyses and synthesis, scientific abstraction,mathematical programming, systematic analyzing, experiment and other research methods. Using abovementioned scientific methods we carried out the scientific research and tried to perfect theoretical and methodological base to solve the problem of debts among the entities by the way of opportunely interfering of the government by economic instruments and mechanisms.

Our scientific research work on the problem of debts among the entities and finding out acceptable solution on it by phased approach consists of the following stages:

The first stage: we developed procedures and rules for complete processing of information of current position of debts among entities which should be arranged in electronic file, in other words we worked out the order and rules to place it in the following special schedule;

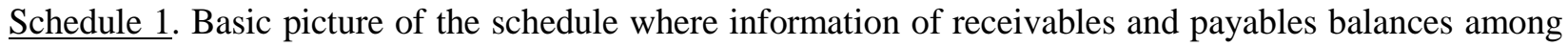
entities is placed.

Thus it is basic picture of the schedule where information of current position of debts among entities $\mathbf{A}_{\mathbf{p}}(\mathrm{p}=1, \mathrm{~m})$ and $\mathbf{B}_{\mathbf{f}}(\mathrm{f}=1, \mathrm{n})$ entities should be placed in series (automatically) and we order to place the following information of current position of debts among $\boldsymbol{m}+\boldsymbol{n}$ entities there. At the same time, the placement of information and if necessary the gradual expansion of the size of the table should be done on the base of definite rules.

It should be pointed that the results of our scientific research work show the following:

During the process of placing the Requisite of entities $\mathbf{A}_{\mathbf{p}}(\mathrm{p}=1, \mathrm{~m})$ and $\mathbf{B}_{\mathbf{f}}(\mathrm{f}=1, \mathrm{n})$ which are pair of nonpaying participants in appropriate cell of 1-column and (or) 1-line of the special schedule the number of all versions which might be appeared amounts 16 .

Information about $\mathbf{D}_{\mathbf{i j}}$-receivables and $\mathbf{K}_{\mathbf{i j}}$ - payables among entities placed in Schedule 1 showed in the following picture: 
Schedule 2. Information about debts among entities.

\begin{tabular}{|c|c|c|c|c|c|c|c|c|c|}
\hline $\begin{array}{c}\text { Requisite of } \\
\text { entities }\end{array}$ & $\mathbf{B}_{\mathbf{1}}$ & $\mathbf{B}_{\mathbf{2}}$ & $\mathbf{B}_{\mathbf{3}}$ & $\cdots$ & $\mathbf{B}_{\mathbf{j}}$ & $\cdots$ & $\mathbf{B}_{\mathbf{f}}$ & $\cdots$ & $\mathbf{B}_{\mathbf{n}}$ \\
\hline $\mathbf{A}_{\mathbf{1}}$ & $\mathrm{D}_{11}$ & $\mathrm{~K}_{12}$ & & $\cdots$ & $\mathrm{K}_{1 \mathrm{j}}$ & $\cdots$ & $\mathrm{D}_{1 \mathrm{f}}$ & $\cdots$ & $\mathrm{K}_{1 \mathrm{n}}$ \\
\hline $\mathbf{A}_{\mathbf{2}}$ & $\mathrm{K}_{21}$ & & $\mathrm{~K}_{23}$ & $\cdots$ & $\mathrm{D}_{2 \mathrm{j}}$ & $\cdots$ & $\mathrm{D}_{2 \mathrm{f}}$ & $\cdots$ & \\
\hline $\mathbf{A}_{\mathbf{3}}$ & $\mathrm{K}_{31}$ & $\mathrm{D}_{32}$ & $\mathrm{~K}_{33}$ & $\cdots$ & & $\cdots$ & $\mathrm{K}_{3 \mathrm{f}}$ & $\cdots$ & $\mathrm{D}_{3 \mathrm{n}}$ \\
\hline$\vdots$ & $\vdots$ & $\vdots$ & $\vdots$ & $\vdots$ & $\vdots$ & $\vdots$ & $\vdots$ & $\vdots$ & $\vdots$ \\
\hline $\mathbf{A}_{\mathbf{i}}$ & $\mathrm{D}_{\mathrm{i} 1}$ & $\mathrm{~K}_{\mathrm{i} 2}$ & $\mathrm{D}_{\mathrm{i} 3}$ & $\cdots$ & $\mathrm{D}_{\mathrm{ij}}$ & $\cdots$ & $\mathrm{K}_{\mathrm{if}}$ & $\cdots$ & \\
\hline$\vdots$ & $\vdots$ & $\vdots$ & $\vdots$ & $\vdots$ & $\vdots$ & $\vdots$ & $\vdots$ & $\vdots$ & $\vdots$ \\
\hline $\mathbf{A}_{\mathbf{p}}$ & $\mathrm{K}_{\mathrm{p} 1}$ & & $\mathrm{D}_{\mathrm{p} 3}$ & $\cdots$ & & $\cdots$ & $\mathrm{D}_{\mathrm{pf}}$ & $\cdots$ & $\mathrm{K}_{\mathrm{pn}}$ \\
\hline$\vdots$ & $\vdots$ & $\vdots$ & $\vdots$ & $\vdots$ & $\vdots$ & $\vdots$ & $\vdots$ & $\vdots$ & $\vdots$ \\
\hline $\mathbf{A}_{\mathbf{m}}$ & & $\mathrm{D}_{\mathrm{m} 2}$ & & $\cdots$ & $\mathrm{K}_{\mathrm{mj}}$ & $\cdots$ & $\mathrm{K}_{\mathrm{mf}}$ & $\cdots$ & $\mathrm{D}_{\mathrm{mn}}$ \\
\hline
\end{tabular}

Source: product of the researcher.

Here:

$\mathbf{A}_{\mathbf{p}}, \mathbf{B}_{\mathbf{f}}$ - the requisite details of the participants of the non-paying pair, that is name of entities, bank account pointed in payment documents and code of bank that serving the account;

$\mathbf{D}_{\mathbf{p f}}$ - the sum of receivables of $\mathbf{A}_{\mathbf{p}}$-entity the requisite details of which are located in cell of 1-column and $\mathbf{p}$-line in regard to $\mathbf{B}_{\mathbf{f}}$-entity the requisite of which is located in cell of $\mathbf{f}$-column and 1-line;

$\mathbf{K}_{\mathbf{p f}}$ - the sum of accounts payable of $\mathbf{A}_{\mathbf{p}}$-entity the requisite details of which are located in cell of 1-column and $\mathbf{p}$-line in regard to $\mathbf{B}_{\mathbf{f}}$-entity the requisite of which is located in cell of $\mathbf{f}$-column and 1-line;

$\mathbf{A}_{\mathbf{p}}(\mathrm{p}=1, \mathrm{~m})$;

$\mathbf{B}_{\mathbf{f}}(\mathrm{f}=1, \mathrm{n})$;

Number of lines in schedule: $i=1, m$;

Number of columns in schedule: $j=1, n$.

Therefore, we can analyze information about debts among entities placed in Schedule 2 in the context of:

- territory (including separate district, town, region);

- banks (bank or branch of the bank opened appropriate bank account of the non-paying pair of participants);

- bank account (including appropriate bank accounts of the non-paying pair of participants of nonpayment such as 20208, 20210 and so on);

- definite date or period;

- chosen entity or a number of entities;

- and other criteria interesting for us. 
The second stage: we worked out the rules for elimination of debts among entities identified by Information placed in Schedule 2.

The third stage: we perfected the following economic-mathematical models reflecting the current position of debts among the entities placed in Schedule 2:

a) regarding receivables and payables among $\mathbf{A}_{\mathbf{p}}(\mathrm{p}=1, \mathrm{~m})$ entities:

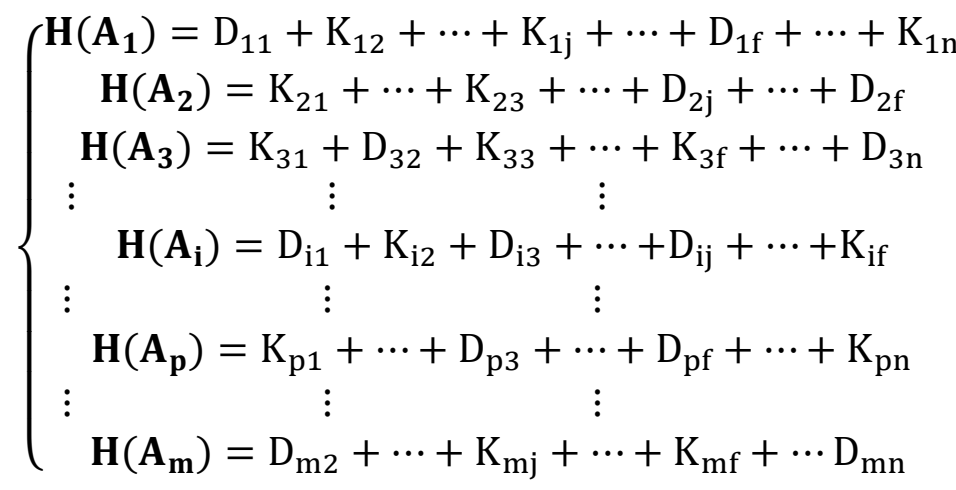

At the same time when it is necessary the information about nonpayment among entities from Schedule 2 can be analyzed by types of debts (receivables or payables) placing it in above showed schedule.

Moreover it on the base of information from Schedule 2 we can conduct the following analysis concerning one entity $\mathbf{A}_{\mathbf{p}}$ which we are interested in.

b) We can evaluate the model of nonpayment for entity $\mathbf{A}_{\mathbf{p}}$ as following:

$$
\mathbf{H}\left(\mathbf{A}_{\mathbf{p}}\right)=\mathrm{K}_{\mathrm{p} 1}+\cdots+\mathrm{D}_{\mathrm{p} 3}+\cdots+\mathrm{D}_{\mathrm{pf}}+\cdots+\mathrm{K}_{\mathrm{pn}}
$$

By the same way on the base of information from Schedule 2 we can conduct the following analysis concerning one entity $\mathbf{B}_{\mathbf{f}}$ which was chosen.

c) We can evaluate the model of nonpayment for entity $\mathbf{B}_{\mathbf{f}}$ as following:

$$
\mathbf{H}\left(\mathbf{A}_{\mathbf{p}}\right)=\mathrm{D}_{1 \mathrm{f}}+\mathrm{D}_{2 \mathrm{f}}+\mathrm{K}_{3 \mathrm{f}}+\cdots+\mathrm{K}_{\mathrm{if}}+\cdots+\mathrm{D}_{\mathrm{pf}}+\cdots+\mathrm{K}_{\mathrm{mf}}
$$

According to above noted rule we can work out an economic-mathematical model of current position of nonpayment of entities for clients of definite bank or entities worked in definite region (as well as in other context we are interested in).

The fourth stage: we describing the methodological basis to analyze and calculate the following indicators of debts in different context using the information from Schedule 2:

In particular, we can calculate the following indicators of receivables and payables of entities $\mathbf{A}_{\mathbf{p}}(\mathrm{p}=1, \mathrm{~m})$ using the information derived from Schedule 2: 
1. Total amount of receivables of entities $\mathbf{A}_{\mathbf{p}}(\mathrm{p}=1, \mathrm{~m})$ is:

$$
\mathbf{S}_{\mathbf{D}}\left(\mathrm{A}_{\mathrm{p}}\right)=\sum_{\mathrm{p}=1}^{\mathrm{m}} \sum_{\mathrm{f}=1}^{\mathrm{n}} \mathrm{D}_{\mathrm{pf}} \quad\left(\mathrm{D}_{\mathrm{pf}}<0\right)
$$

2. Total amount of payables of entities $\mathbf{A}_{\mathbf{p}}(\mathrm{p}=1, \mathrm{~m})$ is :

$$
\mathbf{S}_{\mathrm{K}}\left(\mathrm{A}_{\mathrm{p}}\right)=\sum_{\mathrm{p}=1}^{\mathrm{m}} \sum_{\mathrm{f}=1}^{\mathrm{n}} \mathrm{K}_{\mathrm{pf}} \quad\left(\mathrm{K}_{\mathrm{pf}}>0\right)
$$

3. Total amount of receivables and payables of entities $\mathbf{A}_{\mathbf{p}}(\mathrm{p}=1, \mathrm{~m})$ is:

$$
\mathbf{S}_{\mathrm{H}}\left(\mathrm{A}_{\mathrm{p}}\right)=\sum_{\mathrm{p}=1}^{\mathrm{m}} \sum_{\mathrm{f}=1}^{\mathrm{n}}\left|\mathrm{D}_{\mathrm{pf}}\right|+\sum_{\mathrm{p}=1}^{\mathrm{m}} \sum_{\mathrm{f}=1}^{\mathrm{n}}\left|\mathrm{K}_{\mathrm{pf}}\right| \quad\left(\left|\mathrm{D}_{\mathrm{pf}}\right|,\left|\mathrm{K}_{\mathrm{pf}}\right|>0\right)
$$

4. Balance of total amount of receivables and payables of entities $\mathbf{A}_{\mathbf{p}}(\mathrm{p}=1, \mathrm{~m})$ between each other:

$$
\mathbf{Q}_{\mathrm{H}}\left(\mathrm{A}_{\mathrm{p}}\right)=\sum_{\mathrm{p}=1}^{\mathrm{m}} \sum_{\mathrm{f}=1}^{\mathrm{n}}\left|\mathrm{K}_{\mathrm{pf}}\right|-\sum_{\mathrm{p}=1}^{\mathrm{m}} \sum_{\mathrm{f}=1}^{\mathrm{n}}\left|\mathrm{D}_{\mathrm{pf}}\right| \quad\left(\left|\mathrm{D}_{\mathrm{pf}}\right|,\left|\mathrm{K}_{\mathrm{pf}}\right|>0\right)
$$

In addition, using the information from Schedule 2 total indicators regarding the problem of nonpayment of entities $\mathbf{A}_{\mathbf{p}}(\mathbf{p}=1, \mathrm{~m})$ using the information of can be calculated in the following way:

5. The average remaining amount of debts regarding every entity $\mathbf{A}_{\mathbf{p}}(\mathrm{p}=1, \mathrm{~m})$ faced the problem of nonpayment by exact date is:

$$
\mathbf{X}_{\overline{\mathbf{H}}}\left(\mathrm{A}_{\mathrm{p}}\right)=\frac{1}{\mathrm{~K}} \sum_{\mathrm{p}=1}^{\mathrm{m}} \sum_{\mathrm{f}=1}^{\mathrm{n}}\left(\left|\mathrm{D}_{\mathrm{pf}}\right|+\left|\mathrm{K}_{\mathrm{pf}}\right|\right)=\frac{1}{\mathrm{~K}} \mathrm{H}_{\mathrm{pf}}
$$

There:

$\mathbf{K}$-total number of entities $\mathbf{A}_{\mathbf{p}}(\mathrm{p}=1, \mathrm{~m})$ faced the problem of nonpayment by exact date;

$\mathbf{H}$-total remaining amount of receivables and payables of entities $\mathbf{A}_{\mathbf{p}}(\mathrm{p}=1, \mathrm{~m})$ by exact date;

We can calculate abovementioned indicators concerning amounts of debt of $\mathbf{B}_{\mathbf{f}}(\mathrm{f}=1, \mathrm{n})$ entities which are nonpaying pair of participants in the same way as we did it regarding entities $\mathbf{A}_{\mathbf{p}}(\mathrm{p}=1, \mathrm{~m})$.

The fifth stage: using the information placed in special schedule we worked out the procedures and rules forming the graphic form that can reflect the flow of current position of debts among entities.

The sixth stage: the theoretical base for calculating maximal number of directions in graphic form which reflects the flow of current position of chain order of debts among entities was improved.

The seventh stage: methodological base of analysis of debts scheme on the base of "online flow" theory and evaluation of versions and acceptable ways to prevent existing problems by means of economicalmathematical methods was improved. 
The eighth stage; block-scheme on issue to which provided basis for automated completions of tasks from above stages using special computer program was worked out.

This stages are the complex of scientific innovations achieved during this scientific research work.

In conclusion it should be noted that in order to introduce the developed theoretical and methodological basis to solve the problem of debts among entities positively and in time by interference of government by economic instruments and mechanisms at macroeconomic level it is required:

- firstly, to work out unified base of information of current position of debts among entities in electron file;

- secondly, to develop perfect software of economic mechanisms which would allow to analyze current position of debts among entities and solve it;

- thirdly, to introduce appropriate changes and supplements to legislative acts regarding to the problem of debts;

- fourthly, there is a need of experienced government personnel which would have professional training and economic knowledge to analyze indicators and information reflecting current position of debts as well as to reduce the problem as much as possible.

\section{References}

1. Wee Chian Koh, M. Ayhan Kose, Peter S. Nagle, Franziska L. Ohnsorge, Naotaka Sugawara "Debt and Financial Crises". Policy Research Working Paper.

http://documents.worldbank.org/curated/en/560291579701550183/pdf/Debt-and-Financial-Crises.pdf

2. National newspaper "Public word" (Halq Suzi), January 16, 2017, N 12(6705), p.4

3. Matteo Tomaselli "Economic Gorwth and Public Debt: Beyond Debt-Thesholds, Theoretical and Empirical Issues." Doctoral Thesis

http://pdfs.semanticscholar.org/d8b1/30d4d07b37f229be76d38c63bf4b0779276b.pdf

4. Michail Delyagin. "Economy of nonpayment: how and why we will live tomorrow", Moscow, "Jointstock company Original", p.235

5. N.H.Kobrinski, "Economic cybernetics", Moscow, "Economy", 1982, p.408

6. I.A.Karimov, "We build our future ourselves", Tashkent, "Uzbekistan”, 1999, p.410

\section{Copyrights}

Copyright for this article is retained by the author(s), with first publication rights granted to the journal.

This is an open-access article distributed under the terms and conditions of the Creative Commons Attribution license (http://creativecommons.org/licenses/by/4.0/). 